\title{
Behaviour of High Strength Concrete Using Cement Kiln Dust and Silica Fume
}

\author{
P.Gayathri ${ }^{1}$, Dr. K.Rajasekhar ${ }^{2}$. \\ ${ }^{1}$ P.G student, ${ }^{2}$ Professor Department of Civil Engineering Siddartha Educational Academy Group of \\ Institutions::C. Gollapalli (Vi), Tirupati-517505,A .P, India
}

\begin{abstract}
The present investigation to assess the properties of concrete containing cement kiln dust (CKD). Concrete specimens were prepared with $0 \%$ CKD, $10 \%$ and $20 \%$ CKD as a replacement of cement weight, $10 \%$ and 20\% CKD. Ordinary Portland cement (O.P.C., 53 grade) was used throughout this investigation. The properties of concrete specimens were evaluated by measuring workability (using slump test), compressive strength, split tensile strength and Flexural Strength.. The compressive strength increased in the concrete mixtures including 10\% CKD (as an addition of cement weight) and 5\%, 10\% Silica fume as an addition of cement weight with super plasticizers. A decrease in the compressive strength was noted in the concrete mixtures including 20\%, CKD (as a replacement of cement weight). A similar trend was noted in the split tensile strength and the increase in split tensile strength was less pronounced than that in compressive strength. A similar trend was noted in the flexural strength percent increased when CKD was used in concrete mixtures. The using of silica fume enhanced workability, compressive strength, split tensile strength and flexural strength of the concrete for the types of cement. The ordinary Portland cement concrete mixtures including CKD had almost the same behaviors.
\end{abstract}

Keywords: Cement kiln dust (CKD), Portland cement, Mechanical properties of concrete, Silica fume of concrete, Workability, Super plasticizers

\section{Introduction}

In India, the manufacturing of Portland cement was commenced around the year 1912. The beginning was not very promising and growth of cement industry was very slow. At the time of independence in 1947, the installed capacity of cement plants in India was approximately 4.5 million tons and actual production around 3.2 million tons per year. The large construction activity undertaken during the various 5 years plans necessitated the growth of cement industry. However, until the year 1982, the growth remained stinted due to the complete control exercised by the Government over the cement industry. The partial deep control in 1982 prompted various industrial houses to setup new cement plants in the country. In the last millennium concrete has demanding requirements both in terms of technical performance and economy while greatly varying from architectural masterpieces to the simplest of utilities. It is difficult to point out another material of construction which is as versatile as concrete. Concrete is one of the versatile heterogeneous materials, civil engineering has ever known. With the advent of concrete, civil engineering has touched highest peak of technology. Concrete is a material with which any shape can be cast and with any strength. It is the material of choice where strength, performance, durability, impermeability, fire resistance and abrasion resistance are required. The growth in infrastructure sector led to scarcity of cement because of which the cost of cement increased incrementally. In India, the cost of cement increasing day to day. In order to combat the scarcity of cement and the increase in cost of concrete under these circumstances the use of recycled Cement Kiln Dust, solid wastes, agricultural wastes, and industrial by-products like fly ash, blast furnace slag, silica fume, rise husk, phosphogypsum, etc. came into use. The use of abovementioned waste products with concrete in partial amounts replacing cement paved a role for

1. modifying the properties of the concrete,

2. controlling the concrete production cost

3. to overcome the scarcity of cement, and finally

4. the advantageous disposal of industrial wastes

\section{Literature Review}

Daous (2004) reported results of an investigation into the usage of CKD and fly ash in concrete. Test results showed that satisfactory mechanical strength (a minimum of $94 \%$ of compressive strength of ordinary Portland cement) could still be achieved in blends utilizing $90 \%$ cement and not more than $4 \%$ fly ash. Adequate mechanical strengths (a minimum of $80 \%$ of compressive strength of Portland cement) were achieved in blends utilizing as little as $70 \%$ cement when only kiln dust was blended Maslehuddin et al. (2009) evaluated the properties of cement kiln dust (CKD) blended cement concretes. The percentages of CKD were 0\%, 5\%, 10\% 
and 15\%, replacing cement ASTM C 150 Type I and Type V. The results showed that the compressive strength of concrete specimens decreased with the quantity of CKD. However, there was no significant difference inthe compressive strength of 0 and 5\% CKD cement concretes. A similar trend was noted in the drying shrinkage strain. The chloride permeability increased and the electrical resistivity decreased due to the incorporation of CKD. The performance of concrete with $5 \%$, CKD was almost similar to that of concrete without CKD. Therefore, they suggested to limit the amount of CKD in concrete to 5\%, since the chloride permeability and electrical resistivity data indicatedthat the chances of reinforcement corrosion would increase with $10 \%$ and $15 \%$ CKD. Al-Mabrook (2010) studied the ability of using CKD in mortar and hollow cement bricks. The percentages of CKD were $10 \%, 20 \%, 30 \%, 40 \%$ and $50 \%$ replacing cement.

\section{Materials Used}

3.1 CEMENT: - 53 grade (OPC - Ultratech Cement) was used in the experimental investigation. It was tested for its physical properties in accordance with Indian Standard specifications. The fine aggregate used in this investigation was clean river sand, passing through $4.75 \mathrm{~mm}$ sieve with specific gravity of 2.6. The grading zone of fine aggregate was zone II as per Indian Standard specifications. Machine crushed granite broken stone angular in shape was used as coarse aggregate. The maximum size of coarse aggregate was $20 \mathrm{~mm}$ with specific gravity of 2.60. Ordinary clean portable water free from suspended particles and chemical substances was used for both mixing and curing of concrete.

3.2.FINE AGGREGATE: The fine aggregate obtained from river bed, clear from all sorts of organic impurities was used in this experimental program. The fine aggregate was passing through $4.75 \mathrm{~mm}$ sieve and had a specific gravity of 2.59. The grading zone of fine aggregate was zone II as per Indian Standard specifications. 3.3.COARSE AGGREGATE: Coarse aggregate are the crushed stone is used for making concrete. The commercial stone is quarried, crushed, and graded. Much of the crushed stone used is granite, limestone, and trap rock. The last is a term used to designate basalt, gabbro, diorite, and other dark-colored, fine-grained igneous rocks. Graded crushed stone usually consists of only one kindof rock and is broken with sharp edges. The sizes are from 0.25 to 2.5 in ( 0.64 to $6.35 \mathrm{~cm}$ ), although larger sizes may be used for massive concrete aggregate. Machine crushed granite broken stone angular in shape was used as coarse aggregate. The maximum size of coarse aggregate was $20 \mathrm{~mm}$ and specific gravity of 2.60 .

3.4.WATER :Water fit for drinking is generally considered fit for making concrete. Water should be free from acids, oils, alkalies, vegetables or other organic Impurities. Soft waters also produce weaker concrete. Water has two functions in a concrete mix. Firstly, it reacts chemically with the cement to form a cement paste in which the inert aggregates are held in suspension until the cement paste has hardened. Secondly, it serves as a vehicle or lubricant in the mixture of fine aggregates and cement.

3.5.CEMENT KILN DUST (CKD): Cement kiln dust produced in New Kufa Cement Plant as waste material was used in this study. It was passed through a sieve of size $(0.15 \mathrm{~mm})$. The chemical properties of CKD are reported in Table .

3.6. SILICA FUME:The American Concrete Institute (ACI) defines silica fume as "very fine non-crystalline silica produced in electric arc furnaces as a by-product of the production of elemental silicon or alloys containing silicon". It is usually a gray colored powder, somewhat similar to Portland cement or some fly ashes

\section{Results And Discussions \\ II.1 Compressive Strength Of Cement Kiln Dust and Silica Fume Concrete Compressive Strength Results:}

With $0 \%$ CKD the basic M40 concrete has given the design strength of $48.49 \mathrm{MPa}$ at 28 days and with $5 \%$ Silica Fume the strength has gone up-to 50.90MPa and with $10 \%$ Silica Fume the strength has gone up to $54.90 \mathrm{MPa}$. To further increase the strength properties of concrete combination of CKD with SF is tried in the present project work. With $10 \% \mathrm{CKD}$ and 5\% SF the strength is going up to $56.10 \mathrm{MPa}$, with $10 \% \mathrm{CKD}$ and $10 \%$ SF the strength is further going up-to $58 \mathrm{MPa}$. Similarly With $20 \%$ CKD and 5\% CSF the strength is reduced to $47 \mathrm{MPa}$, with $20 \% \mathrm{CKD}$ and $10 \%$ SF the strength is $39 \mathrm{MPa}$

\section{Split Tensile Strength Of Cement Kiln Dust and Silica Fume Concrete Split Tensile Strength Results}

With 0\% CKD and 0\% SF the basic M40 concrete has given design strength of 4 MPaat 28 days. With $5 \%$ Silica Fume the strength has gone up-to $4.20 \mathrm{MPa}$ and with 10\% Silica Fume the strength has further gone up to 4.38MPa. With CKD10\% and $5 \%$ CSF the strength is going up to $4.45 \mathrm{MPa}$ and with CKD10 \% and $10 \%$ $\mathrm{SF}$ the strength is further going upto $4.56 \mathrm{MPa}$. Similarly With $20 \% \mathrm{CKD}$ and $5 \% \mathrm{SF}$ the strength is reduced to $4.13 \mathrm{MPa}$, with $20 \% \mathrm{CKD}$ and $10 \% \mathrm{SF}$ the strength is $4.04 \mathrm{MPa}$

Split Tensile Strength Of Cement Kiln Dust and Silica Fume Concrete

With $0 \%$ CKD and $0 \%$ SF the basic M40 concrete has given design strength of $6.4 \mathrm{MPa}$ at 28 days. With 5\% Silica Fume the strength has gone up-to 6.63MPaand with 10\% Silica Fume the strength has further 
gone up to $7.28 \mathrm{MPa}$. With $10 \% \mathrm{CKD}$ and $5 \% \mathrm{SF}$ the strength is going up to $7.41 \mathrm{MPa}$ and with $10 \% \mathrm{CKD}$ and $10 \% \mathrm{SF}$ the strength is further going upto 7.62MPa. Similarly With $20 \% \mathrm{CKD}$ and $5 \%$ SF the strength is reduced to7.1 $\mathrm{MPa}$, with $20 \% \mathrm{CKD}$ and $10 \% \mathrm{SF}$ the strength is $6.85 \mathrm{MPa}$

Table No. 1 Average Compressive Strength for M40

Table No. 2 Tensile Strength for M40

\begin{tabular}{|l|l|l|l|l|}
\hline \multirow{2}{*}{ Sample } & \multicolumn{4}{|c|}{ Compressive Strength (MPa) } \\
\cline { 2 - 5 } & $\begin{array}{l}3 \\
\text { Days }\end{array}$ & $\begin{array}{l}7 \\
\text { Days }\end{array}$ & $\begin{array}{l}\text { 28 } \\
\text { Days }\end{array}$ & 56 Days \\
\hline Concrete & 21.77 & 31.86 & 48.49 & 52.2 \\
\hline CKD0/SF5 & 22 & 35.9 & 50.9 & 55.4 \\
\hline CKD0/SF10 & 24 & 38.2 & 54.9 & 58.7 \\
\hline CKD10/SF5.0 & 23 & 36.7 & 56.1 & 60 \\
\hline CKD10/SF10 & 24.36 & 38.28 & 58 & 60.7 \\
\hline CKD20/SF5 & 22.3 & 35.33 & 53 & 56.4 \\
\hline CKD20/SF10 & 21.29 & 33.32 & 50.66 & 53.39 \\
\hline
\end{tabular}

\begin{tabular}{|l|l|}
\hline \multirow{2}{*}{ Sample } & $\begin{array}{l}\text { Tensile } \\
\text { Strength }\end{array}$ \\
\cline { 2 - 2 } & for 28 Days \\
\hline Concert & 4 \\
\hline CKD0/SF5 & 4.2 \\
\hline CKD0/SF10 & 4.38 \\
\hline CKD10/SF5.0 & 4.45 \\
\hline CKD10/SF10 & 4.56 \\
\hline CKD20/SF5 & 4.13 \\
\hline CKD20/SF10 & 4.04 \\
\hline
\end{tabular}

Table No. 3 Flexural Strength for M40 using CKD \& SF

Fig.No: 1. Comparision values of compressive strength for M 40

\begin{tabular}{|l|l|}
\hline Sample & $\begin{array}{l}\text { Flexural } \\
\text { Strength }\end{array}$ \\
\cline { 2 - 2 } & for 28 Days \\
\hline CON & 6.4 \\
\hline CKD0/SF5 & 6.63 \\
\hline CKD0/SF10 & 7.28 \\
\hline CKD10/SF5.0 & 7.41 \\
\hline CKD10/SF10 & 7.62 \\
\hline CKD20/SF5 & 7.1 \\
\hline CKD20/SF10 & 6.85 \\
\hline
\end{tabular}
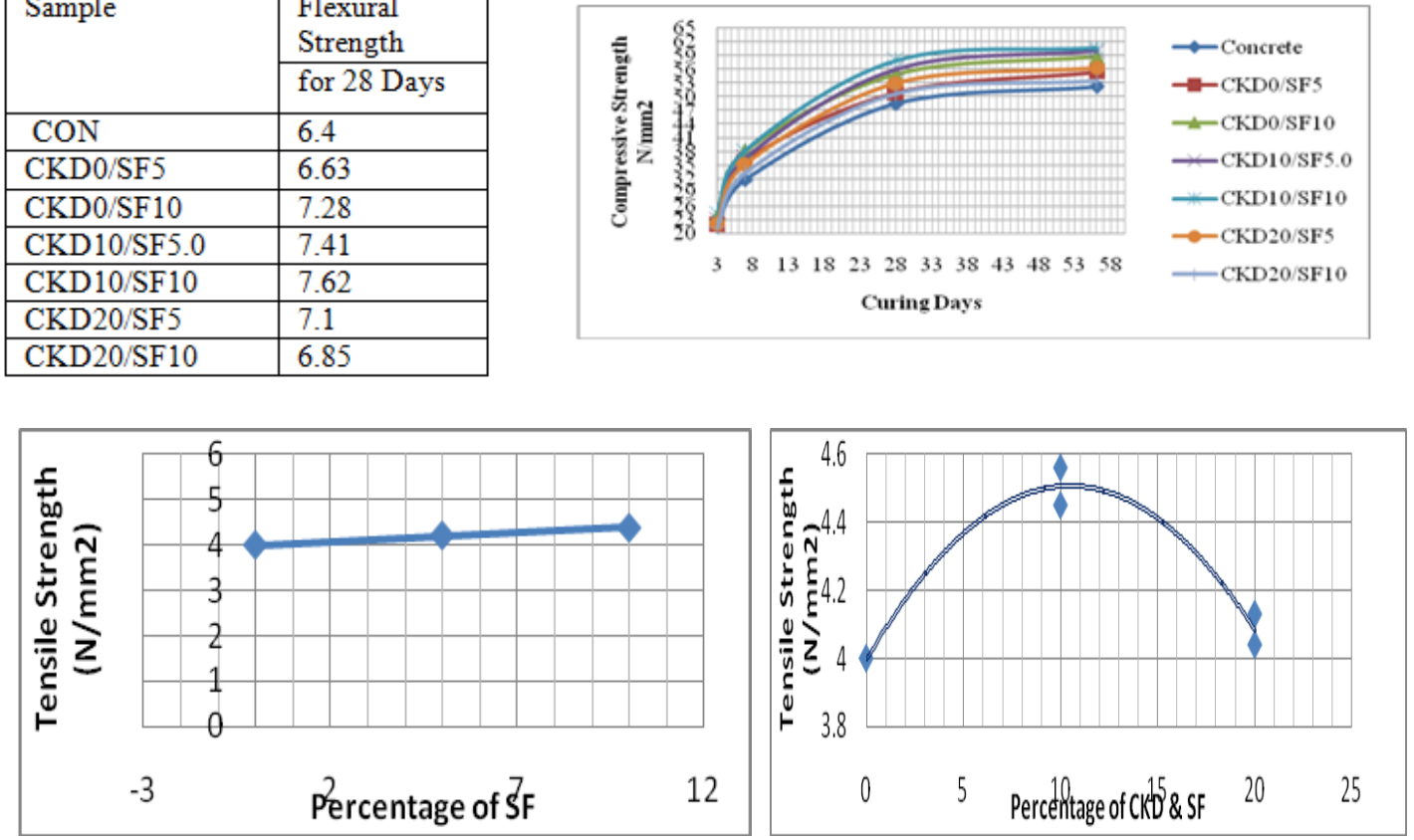

Fig.No:2. 28 days curing of Tensile Strength for M40 using different \%SF
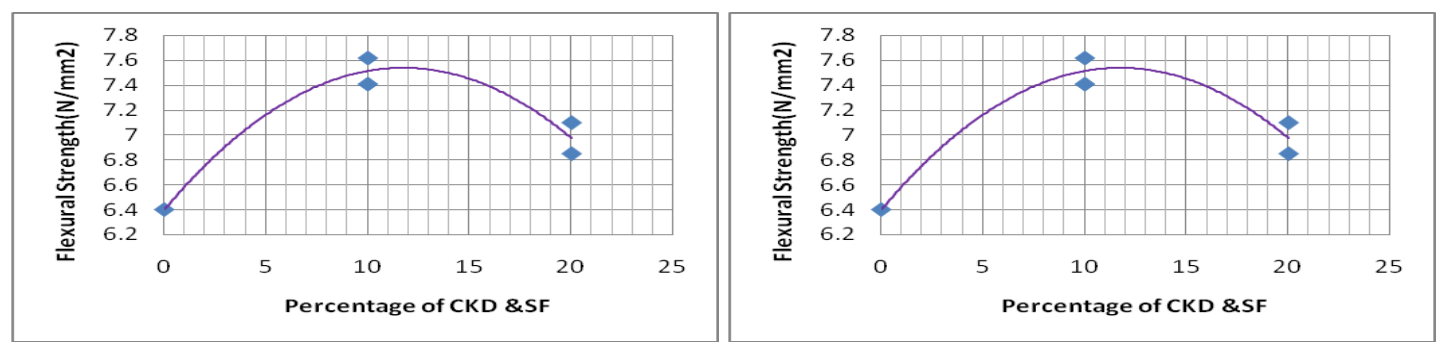

Fig. No: 3. 28 days curing of Tensile Strength for M40 using different \%CKD\&SF

\section{Conclusion}

Based on the present experimental investigation, the following conclusions are drawn

1. Cement replacement with $10 \%$ CKD leads to increase in Compressive Strength, Split Tensile Strength and Flexural Strength. 
2. For M40 Grade with CKD $10 \%$ the percentage increase in Compressive Strength, Split Tensile Strength and Flexural Strength are $13.21 \%, 9.5 \%$ and $13.75 \%$ respectively

3. There is an increase in Youngs Modulus of Concrete for M40 \& M50 with CKD 10\% is $20.16 \%$ and $26.38 \%$ respectively higher than Conventional Concrete

4. $20 \%$ CKD appears to be the optimum in the Standard concrete mix like M40 without any admixtures. The highest compressive strength with $20 \% \mathrm{CKD}$ and $10 \% \mathrm{SF}$ appears to be the optimum in the present blended concrete mixes.

5. For M40 Grade with CKD 10\% and Silica Fume 10\% the percentage increase in Compressive Strength, Split Tensile Strength and Flexural Strength are $19.6 \%, 14 \%$ and $19.06 \%$ respectively

\section{References}

[1]. Al-Mabrook, F.A. 2010. Utilization of dust profile path of cement factory in producing low-cost building materials. Civil Department, College of Engineering, Qar Younis, Libya. The 11th Arabic Conference of Mineral Wealth. Trablus

[2]. ASTM C 143-89. 1989. Standard test method for slump of hydraulic cement concrete. Annual Book of ASTM Standards, 04.02: 8586.

[3]. ASTM C 496-86. 1989. Standard test method for splitting tensile strength of cylindrical concrete specimens. Annual Book of ASTM Standards, 04.02: 259-26

[4]. ASTM C 494-82. 1982. Standard specification for chemical admixtures for concrete. Annual Book of ASTM standards, Philadelphia.

[5]. B.S.1881. Part 116. 1989. Method for determination of compressive strength of concrete cubes. British Standards Institution, 3 pp.

[6]. Daous, M. A. 2004. Utilization of cement kiln dust and fly ash in cement blends in Saudi Arabia. Chemical and Materials Engineering Department, KAAU. Eng. Sci., 15 (1): 33-45 (1425 A.H.).

[7]. Iraqi Organization of Standards IQS No. 5. 1984. Iraqistandard specification for Portland cements, ICOSQC .Baghdad, Iraq.

[8]. Iraqi Organization of Standards IQS No.45. 1984. IraqiNstandard specification for aggregate, ICOSQC, Baghdad, Iraq.

[9]. Maslehuddin, M., Al-Amoudi, O.S.B., Rahman, M.K. and Barry, M.R. 2009. Properties of cement kiln dust concrete. Center for Engineering Research, Research Institute, King Fahd University of Petroleum and Minerals, Dhahran 31261, Saudi Arabia, Construction

[10]. and Building Materials, 23: 2357-2361.

[11]. Rahman, M. K., Rehman, S. and Al-Amoudi, O.S.B. 2011. Literature review on cement kiln dust usage in soil and waste stabilization and experimental investigation.Center for Engineering Research, Research Institute, King Fahd University of Petroleum and Minerals, Dhahran, Saudi Arabia. www.arpapress.com/ Volumes/Vol7Issue1/IJRRAS_7_1_12.pdf.

[12]. Shoaib, M. M., Balaha, M. M. and Abdel-Rahman, A. G. 2000. Influence of cement kiln dust on mechanical properties of concrete. Cement and Concrete Research, 30 (2): 371-377. (Cited by Wang et al., 2002).

[13]. Wang, K., Maria S. Konsta-Gdoutos and Surendra P. Shah. 2002. Hydration, rheology, and strength of ordinary Portland cement (OPC)-cement kiln dust (CKD)-slag binders. ACI Materials Journal/March-April, 99 (2):173-179.

[14]. Abdullahi M. 2005. Compressive Strength of sandcrete Blocks in Bosso and Siroro areas of Minna, Nigeria. Assumption University Journal of Technology. 9(2):126-132.

[15]. Abo-El-Enein S.A, Hekal E.E., Gabi N.A and El-Barbay M.I. 1994. Blended cements containing cement kiln dust.Silicate Industrial. 59(9-10).

[16]. Barry R. 1969. The Construction of Building. Crosby Lockwood, London, England. Vol. 1. pp. 54-55 and 94. 